\title{
Constitutional Law and International Law at the Turn of the Century*
}

Prof Dr Jochen Abr. Frowein, Director of the Max-Planck-Institute for Comparative Public Law and International Law former Vice-President of the European Commission of Human Rights

\section{Introduction}

Centuries are artificial landmarks created by men. However, they are useful and even necessary to gain orientation in the past which may be important for the future. To consider how Constitutional Law or International Law were understood in 1900 means to notice the immense changes which have taken place since then. International Law and Constitutional Law are two circles in a difficult tension which may tend to become one. Artwork symbolising the tension between these two circles can be seen at the entrance to the new Max-Planck-Institute building in Heidelberg, Germany.

\section{Constitutional Law at the End of the 20th Century}

History has seen several waves of constitution-making in the 20th Century. The first came particularly in Europe after the First World War. One should not forget that the Weimar Constitution of 1919, in spite of the tragic history of the Weimar State, was a constitution with many remarkable elements. It is not by accident that it was the prime model for the French Constitution of 1958. The second important wave of constitution-making occurred after World War II. Again we may say that the German Constitution of 1949 stands out as a remarkable example. Many of the other constitutions immediately after World War II were in fact communist constitutions or became communist systems soon after.

Probably the most remarkable phenomenon in constitution-making in this century is the final victory of liberal constitutions which based themselves on rule of law, on Rechtsstaat, on fundamental rights and on a meaningful control of Public Powers, particularly full constitutional courts.

Paper delivered at the first Colloquium Constitution and Law held at Potchefstroom on 31 October 1997. This paper was first published by the Konrad-Adenauer-Stiftung in their Seminar Report of the Colloquium (Johannesburg 1998) 
The Grundgesetz of 1949 was in all respects a direct answer to the tragic totalitarian history which Germany had known between 1933 and 1945. The formal guarantee of human dignity was a direct response to Auschwitz and Dachau. The broad jurisdiction of the Federal Constitutional Court in Germany showed scepticism vis-à-vis democratic decision making wherever fundamental rights of citizens or fundamental principles of constitutional law are at issue.

When other parts of Europe and the world freed themselves from totalitarian rule, similar developments took place. First, the constitutions on the Iberian Peninsula accepted the same principles and introduced wide powers for constitutional courts.

Then, in 1989, 200 years after the French Revolution, history made a turn in Europe as well as in South Africa. Constitutions were adopted which wereunderstood as being a victory over the totalitarian or partially totalitarian rule which had existed before.

\subsection{Fundamental Principles of the State - Staatszielbestimmungen, Rechtsstaat, Sozialstaat}

After the destruction of World War II and the extreme impoverishment of large parts of the German population, it was not by accident that the framers of its constitution laid down the principle of Sozialstaat - a social state - as a fundamental principle on the same level as the Rechtsstaat - the rule of law - in the German Constitution. Of course, compared with the Weimar Constitution no detailed social rights were laid down because the drafters came to the conclusion that the details must be left to the legislature. Courts could not enforce social rights, according to that view.

In constitutional doctrine, the meaning of the principle of Sozialstaat has long been debated. In constitutional practice it was never really doubted that all state organs in Germany had to respect the specific goals of a social state, particularly caring for those in need. Here, the most important distinction between German and American Constitutional Law is to be seen.

In practically all the new constitutions, the principle of the social responsibility of the state has been confirmed as a common European constitutional principle. But this is also true 
outside of Europe as the South African Constitution shows. One may ask whether this is an area where a great challenge is about to develop to US-constitutional law. After the disappearance of the east-west divide, the social issues and the way to deal with them it may become even more important.

Art. 7 of the Russian Constitution is a proper description of the responsibility of the state for social justice. According to art. 2 of the new Polish Constitution, the Republic of Poland is a democratic Rechtsstaat which will implement the principles of social justice. Art. 20 provides for a Soziale Marktwirtschaft - social market economy - based on free economic activities, private property and solidarity as the economic order for Poland. The South African Constitution refers to social justice in the preamble and lays down a number of detailed social rights as fundamental principles. All these rights are qualified by the statement that the state must take reasonable legislative and other measures, within its available resources, to achieve the progressive realization of each of these rights.

It is certainly correct that the realization of social rights in the difficult transformation conditions prevailing in many of the new democracies creates specific problems. However, it would seem to be of utmost importance to keep the issue of social responsibility of the state within the constitutional sphere. A constitution at the end of the 20th Century, I propose, cannot be based on the idea that it is not a constitutional issue whether people may starve in the streets or not. Southern European countries such as Italy, Spain and Portugal have developed remarkable case-law by the constitutional courts concerning social rights.

\subsection{Traditional Bills of Rights}

All modern constitutions contain detailed Bills of Rights. In Central and Eastern Europe the important distinction between the new and the communist constitution may be seen in the nature of these fundamental rights. They also existed frequently in rather detailed description in the communist constitutions. However, the context of the constitution already showed that these fundamental rights were subjects to the system of so-called democratic centralism. They were conditioned by the communist dogma. The new bills of rights are clearly intended to be a meaningful basis for the whole legal system. 
A comparison of different bills of rights is of interest. However, the importance of such a comparison should not be overestimated. What is much more important is the way these rights are protected in practice by independent courts, and particularly by special constitutional courts. One could probably argue that it is only where constitutional courts or courts with a specific responsibility in that regard have been given the mandate to interpret bills of rights, that they developed fundamental rights into foundation stones of the legal system.

The specific formulation of fundamental rights may therefore not really be the key to their role in the legal order. Where a constitution contains a clear recognition of the idea of fundamental rights, even rather defective provisions can be used in a meaningful way. The doctrine of unwritten fundamental rights in Switzerland - which must be seen as one of the great achievements of the Swiss Federal Tribunal and the Swiss constitutional doctrine - is a good example of that.

What is more important when analyzing bills of rights is the specific way in which restrictive clauses are formulated.

The German Federal Constitution of 1949 was one of the first constitutions which paid much attention to the necessity to formulate restrictive clauses in a manner that they cannot be used to completely empty the fundamental right of any real meaning.

In that respect one should not accept a view frequently held by American constitutional lawyers who have to work with a constitution drafted at the end of the 18th century before anybody had come to the idea that one should carefully formulate restrictive clauses with fundamental rights. I shall not forget Professor Dworkins' argument during the discussion with seven South African Constitutional experts held at Ditchley Park, Southern England, where he expressed the view that fundamental rights with restrictive clauses are not worth the ink with which they are written. With all due respect for the man, I had no difficulty to criticize his position rather strongly.

The restrictive clauses in the new constitutions are interesting because they all try to limit the possibilities of the restriction. Section 36 of the South African Constitution is a very detailed limitation of rights clause which attempts to restrict the possibility of limitations in a very 
rational manner. The new Polish Constitution is of the same nature. According to art. 31 of the Polish Constitution, restrictions must be laid down by law and can only go as far as they are necessary in a democratic state for safety, public order, protection of the environment, health and public morality, or the rights and freedoms of others. The restrictions must not violate the nature (Wesen) of the freedoms and rights.

It is easy to see that these provisions are influenced by art. 19 of the German Constitution of 1949 as well as by the restrictive clauses of the European Convention on Human Rights. The European Commission and Court of Human Rights have clarified the need for a restrictive approach to limitation clauses in many decisions. Only a strong test of proportionality may show whether a specific restriction is compatible with the nature of the right or not.

All bills of rights contain many rather vague formulations. They need to be concretized in specific cases by decisions of a constitutional court. They may then more and more become a meaningful check for governmental powers in general. The Swiss constitutional lawyer Hans Huber has described fundamental rights as Gegenrichtung in der Rechtsordnung - opposite direction in the legal order. To a certain extent one may be able to compare fundamental rights in a legal order to the conscience of human beings. All acts of the legal order should be tested on the basis of fundamental rights provisions.

\subsection{Constitutional Courts}

Almost all new constitutions have introduced constitutional courts. During the interwar period, Austria and Czechoslovakia had already established constitutional courts, however, for Czechoslovakia, the court did not really become active and for Austria its jurisdiction was very limited. It was clearly the example of the Federal Constitutional Court of the Federal Republic of Germany which became of great importance for the new wave of constitutions after 1989.

Some of the new courts have been extremely activist from the very beginning. This is certainly true for the Hungarian Constitutional Court, but there are others as well. The Russian Constitutional Court in its first composition tried to become one of the main political organs. This lead the Court and its President Sorkin into great difficulties. It seems that the present Court takes a completely different approach. 
Constitutional courts can solve disputes between political organs and they can protect fundamental rights; they cannot, however, become active political organs. This is of particular importance. The line cannot be easily drawn, but it must be in the general attitude and in the minds of constitutional court judges, otherwise the court will risk its neutrality being brought into question and this can only be damaging to its authority.

Germany has recently had some examples of that where the Court gave the impression that it saw law reform in general as its task.

\subsection{The Constitution of the Political Organs}

The emphasis put on fundamental rights should not make us overlook the importance of the rules for establishing and legitimising the political organs in a constitution. It is of course in this area where constitutions differ considerably.

In many of the Central and Eastern European countries, the French model of a presidential system as laid down in the French Constitution of 1958 has been copied to some extent. It has already been mentioned that the French Constitution of 1958 used the Weimar Constitution of 1919 as its model, particularly for the distribution of powers between president, government and parliament.

Experience shows that it is extremely difficult to define the powers of the President vis-à-vis the government and the parliament in an absolutely watertight manner. Disputes in several of the Central and Eastern European countries show that it depends greatly on the activity of the presidents and to what extent they will try to extend their powers.

Particularly, the role of the president as commander-in-chief of the armed forces may give rise to difficulties with the government responsible before parliament. One could recently study that in detail in Estonia. Where the president has his or her own law-making competence, as in Russia, problems with Parliament are almost unavoidable.

The South African Constitution is of particular interest in this context. The president has almost the same full powers as that of the United States president, but he is elected by the 
Parliament. Parliament cannot remove him by a vote of no confidence, as it is the rule for parliamentary systems. One may say that the South African President is comparable to the Federal Chancellor in Germany except for the impossibility of removing him from office by a vote of no confidence. The South African President can only be removed for serious misconduct by a 2/3 majority of Parliament (section 89).

In the relationship between the political organs of a state the role of the Constitutional Court should be seen as rather different from its role concerning the protection of fundamental rights. For the different competences and functions of the political organs, it will be the rare exception that the Constitutional Court will be asked to decide issues. Such a decision will, of course, be of great importance for the political system. However, it will occur only in rather exceptional cases. What is most important is that the political organs themselves develop a clear understanding of their role within the framework of the constitution. The actors in the political sphere must be constitutionally minded.

It is probably here where we can learn from the unwritten British constitutional law. The existence of constitutional conventions which create a non-legal framework for the political powers seems to be of great importance, even in systems with written constitutions. These constitutional conventions may slowly also influence constitutional law. The German Federal Constitutional Court has in several cases underlined the importance of the practice of the constitutional organs when interpreting the constitution by their behaviour.

We all know that legal instruments cannot be understood without their development in practice. This is all the more true for constitutions which create a rather loose framework for the activities of political powers. In that context it should be stressed how important the role of a constitutional court is for protecting political opposition and political minorities. Majorities always have a certain tendency to make it more difficult for the minority to become the majority.

The role of the constitutional court to protect in a meaningful way the chances of the minority is really of great importance. This refers to the whole area of electoral laws, the role of the political opposition in parliament, including its possibility to question and challenge the government, and to ask for the investigation of political scandals. 
When the Federal Constitutional Court in Germany protected the successor party to the former state party of the GDR in the first federal elections, it really played the role of watchdog for political minorities in a very meaningful way.

\subsection{Conclusion}

It is a great achievement for the development of legal culture in the world that the western idea of a free democratic order based on rule of law is now recognized in vast parts of the world as a general principle. It cannot be overlooked, of course, that to implement this very demanding principle, much more is needed than a well drafted constitution. It is finally the recognition by all those subject to the constitution, particularly political parties, other associations and the people in general, which will decide on the fate of a constitution.

In Central and Eastern Europe we can see how difficult it is to overcome the legacy of half a century of totalitarian rule. It was the specific nature of the communist system which created the view that law in itself is not a meaningful check on government and has no reality in itself. The dignity of law was not recognized in the communist system at all.

It will be of crucial importance to what extent the societies in Central and Eastern Europe will be able to reestablish a feeling for the dignity of law in that very real sense. Law as something which has a role by itself beyond the specific will of politicians is a great cultural achievement. "Government by law and not by men" in the old American formula supposes a specific cultural development which is not at all easy to secure.

\section{Public International Law at the End of the 20th Century}

Public International Law has during the 20th century also seen different waves of development. The beginning of the century saw the first promising attempts to agree on rules of peaceful settlement of disputes and codification. World War I abruptly ended that period. The League of Nations was an ambitious undertaking. However, because of its composition and its limited competence it was never able to achieve its goals. With World War II came the greatest catastrophe for relations among states and for a system which had already banned the war as a means of politics. 
The United Nations, formed after World War II, was the consequence of these developments. 150 years after Immanuel Kant's famous publication Zum ewigen Frieden (which had appeared in 1795) the UN Charter's comprehensive prohibition of the use of force in art. 2 para. 4 and the introduction of a collective security system in Chapter VII was the establishment of the Friedensbund - or confederation of peace in the sense of Kant. Of course, in 1945 no realist was of the opinion that the use of force among states would stop after the coming into force of the Charter. However, the principle proposed by Kant, according to which the use of force among states should not be lawful, was recognized.

It was only after 1990 that the system established in 1945 could really be tested. During the long phase of the cold war the United Nations could not function because of the veto system. After 1990, the number of Security Council Resolutions which lay down mandatory enforcement measures on the basis of chapter VII has increased enormously. The rather severe possibilities of the Security Council are already available where there is a "threat to the peace." There is no abstract definition of that notion possible and the Security Council has a very broad discretion.

The development after 1990 has shown that the Security Council can become a directorate for the Community of Nations with broad powers. Where the permanent members are unanimous and a majority of the 15 states of the Council is available, interventions of a far-reaching nature can be brought about lawfully. One should not conclude therefrom that there are no controls whatsoever. The procedure of decision making in those countries which have a republican form of government in the sense of Kant is a very meaningful instrument of control. There is also a need to justify resolutions on the basis of general principles before the community of states, particularly before the General Assembly of the United Nations.

Besides the establishment of the confederation of peace, in the sense of Kant, worldwide recognition of human rights is the greatest change in the nature of public international law in the second half of the 20th century.

After the experiences of dictatorship and the atrocities of World War II and the Holocaust, the United Nations General Assembly adopted the Declaration of Human Rights in 1948. Europe can be proud to have established the European Convention on Human Rights on the basis of this Declaration as the first system that has meaningful control instruments. 
The case law of Commission and Court may be seen by me - as somebody who has been a member of the Commission for 20 years - in a biased way. It cannot, however, be overlooked that what we have here is an international system of developing fundamental rights which has become of great importance for the member states. Decisions of Commission and Court have considerably influenced the legal system in member states.

Looking at the results of the European Convention system, one may say that the minimum guarantees for criminal procedure, the protection of freedom of expression (as with the press) has been developed by Convention Law with great impact on the national legal systems. We are in the process of witnessing the extension of the European Convention to the former communist countries and we will see to what extent comparable development will take place there. But also on the worldwide level it is of great importance that human rights are now recognized as a general limitation of state power

An evaluation of international law at the end of this century would not be complete without reference to the global systems of regulation for important areas which are set up by multilateral treaties. The UN Convention on the Law of the Sea is a very good example. It is a codification with immediate applicability for the region which comprises two-thirds of our globe. It seems to me that public international law at the end of this 20th century has increasingly left the structure of a mere system of legal coordination among states. What are considered to be public law structures in the tradition of continental European legal thinking has been recognized by public international law.

Public law categories in this sense are those which establish specific structures to protect the common interest and to solve global or regional problems, where the idea that it is mainly the sovereignty of each state which should be protected is no longer appropriate.

These principles are, of course, most visible in the area of regional structures, for instance in the European Union. The Union is not a State and it has no state constitution, but it has a Union Constitution which in important respects increasingly resembles a State Constitution. Important sovereign rights are no longer under the jurisdiction of the European states but are being exercised through common structures by specific organs set up for them. It therefore makes sense to speak of a European Constitution for the limited powers attributed to the 
Union system. The principles rule of law and of democracy are of great relevance also for this European constitutional system.

It is furthermore of great importance that the idea of constitutional rules friendly to the international legal system has gained ground in the constitutions of many of the new democracies. Art. 55 of the French Constitution of 1958 which gives preeminence to rules of treaty law over national law, is now the rule in many of the new democracies. With regard to issues of European Law, it is clear that European Law must be respected as the paramount international legal order. In principle this system is applied without difficulty throughout Europe.

One may wonder whether sections 231 and 232 of the South African Constitution are really in line with the modern development concerning the relationship of international law and municipal law. In both provisions, acts of parliament are generally given priority over international customary or international treaty law. However, section 233 contains a very important rule of interpretation. Every court must prefer any reasonable interpretation of the legislation that is consistent with international law over any alternative interpretation that is inconsistent with international law. With such a provision it is quite possible to arrive at a harmony between international law and municipal law. It will be extremely rare that a parliament with open eyes will go against a binding international law commitment which the state has entered into. Where courts really look to that interpretative rule, they can do much with it. It is a challenge for lawyers to make courts aware of such cases.

\section{Conclusion}

At the end of the 20th century constitutional law and international law seem to have overcome the great challenges of destruction and neglect which have been so prominent during this century. We all know that there is no guarantee for the future, however, the victory of the principles enshrined in liberal constitutions and in the United Nations Charter is something quite important which the developments after 1989 have brought about.

When I first spoke in South Africa in late January 1989, I was Vice-President of the European Commission of Human Rights. Since this official capacity could have raised questions as to my accepting an invitation by the South African Lawyers Association, I gave as a justification 
for my acceptance of the invitation that I could not believe that a country deeply influenced by Dutch and British legal thinking would not overcome the difficulties contained in the constitutional system at that time which negatively impacted on the dignity of the human being for the majority of the population.

I could not foresee that it would only take a few months until these principles of Rechtsstaat and democracy started their victory. South Africa is to be congratulated for that development. 